\title{
Aesthetic Characteristics of Glocalism in Flight Attendants' Uniform Design
}

\author{
Ji U Kim ${ }^{1)}$, Jang Hyeon $\mathrm{Kim}^{2)}$, and Young Sam Kim ${ }^{2) \dagger}$ \\ ${ }^{1)}$ Dept. of Fashion, Graduate School, Chung-Ang University \\ ${ }^{2)}$ Dept. of Fashion Design, College of Arts, Chung-Ang University
}

\begin{abstract}
This study considers the expressive types of 'Glocalism' trends and its inherent aesthetic characteristics through the analysis of flight attendants' uniform design. The following is the conclusions regarding the glocalism trend according to the analysis of airline uniform design that reflect it. First, the design approach was developed appropriating the whole or parts of traditional attire and applying decorative items in terms of a formal aspect. Secondly, the colors of the airline's homeland symbols or natural environment were used while, thirdly, the fabrics represent glocalism by employing folk elements of the region and patterns of nature for a uniform design. Induced from these design analyses, the aesthetic characteristics of airline uniforms reflecting glocalism are traditionality, naturality, and compromisability. To begin with, traditionality is what is realized in interpreting the historical aesthetics in a contemporary perspective, contributing in inspiring the historical value of the homeland and contributing to the establishment of identity by applying forms and colors of traditional garments with folk patterns on a uniform design. In addition, naturality means the reorganization of unprocessed pure nature, expressing the image of nature through colors taken from the natural environment or motifs of the regional plants. Finally, combining general sensibilities with diverse cultural features, compromisability is realized as a modern design which combines a standardized uniform with the aesthetic components of the local environment and traditional garments.
\end{abstract}

Key words : glocalism, images of flight attendants, uniform designs, the aesthetic characteristics, uniform of flight attendants

\section{Introduction}

Contemporary people of society gradually began to concern about regional particularities and affirmative acceptance regarding pluralistic cultures accelerating a progress of delocalization and globalization based on development of transportation and devices of communication. Accordingly, Glocalism, combination of regionalization and globalization, provides new motives concerning the creation of diverse designs through the ages of 'universal design' in constantly globalized trends. Especially, the glocalism trends shown in a uniform for an airline company which strongly pursues high value on the formation of a positive image in order to sustain their customer attractions would be non-verbal communications by means of emotionally implying corporate messages or identities through visual methods(Kim \& Kim, 2013). Therefore, uniforms of flight attendants describes the distinguished implications of each airline company, and they have a close relationship with present trends of glocalism by reflecting regional characteristics through delivering immanent meanings.

The latest research related to the study shows that 'The history of

$\dagger$ Corresponding author; Young Sam Kim

Tel. +82-31-670-3278, Fax. +82-31-676-9932

E-mail: proyskim@cau.ac.kr
glocalization(Choi, 2009)', 'A study on glocal contents planning and strategy of address in local television(Im \& Kim, 2013)', 'The study of symbolic images in modern fashion design adopting the dualistic meanings of uniform(Kwon, 2011)', 'The effects of flight attendant's uniform design on uniform satisfaction and select airline(Kim \& Park, 2013)' were accomplished. Though conducted various preceding research, the majority of researches focused on the trend of glocalism in terms of the cultural phenomenon or historical aspect or the uniform design in fashion design or marketing fields. Therefore, this research aimed to analyze the glocalism trend that appeared in designs of flight uniform for the necessity of the academic association between glocalism and a flight uniform.

The purpose of this research is to examine the glocalism trend that has appeared in female flight attendants' uniform design over the last five years according to fashion design elements of shape, color and fabric and their inherent aesthetic characteristics. On the basis of findings, it can be identified how notions of glocalism is projected in the uniform design which contains practicality and functionality as key principals, and the significant aim is in proposing fundamental data in designing uniforms with a combination of beauty peculiar to the region and global sensibility for global corporations or international events.

The specified process for the research is as follows. First, general 
Table 1. Airlines selected more than twice consecutively on the top ten lists for recent five years

\begin{tabular}{|c|c|c|c|}
\hline Year & \multicolumn{2}{|c|}{$\begin{array}{l}\text { Airlines selected on the top } \\
\text { ten lists for recent five years }\end{array}$} & $\begin{array}{l}\text { Airlines selected more than twice consecutively on the } \\
\text { top ten lists for recent five years }\end{array}$ \\
\hline \multirow{5}{*}{2009} & 1. Cathay Pacific Airways & 6. Qantas Airways & \multirow{25}{*}{$\begin{array}{l}\text { 1. Asiana Airlines } \\
\text { 2. Air New Zealand } \\
\text { 3. Cathay Pacific Airways } \\
\text { 4. Etihad Airways } \\
\text { 5. Emirates } \\
\text { 6. Garuda Indonesia } \\
\text { 7. Malaysia Airlines } \\
\text { 8. Qantas Airways } \\
\text { 9. Singapore Airlines } \\
\text { 10. Thai Airways }\end{array}$} \\
\hline & 2. Singapore Airlines & 7. Etihad Airways & \\
\hline & 3. Asiana Airlines & 8. Air New Zealand & \\
\hline & 4. Qatar Airways & 9. Malaysia Airlines & \\
\hline & 5. Emirates & 10. Thai Airways & \\
\hline \multirow{5}{*}{2010} & 1. Asiana Airlines & 6. Etihad Airways & \\
\hline & 2. Singapore Airlines & 7. Qantas Airways & \\
\hline & 3. Qatar Airways & 8. Emirates & \\
\hline & 4. Cathay Pacific Airways & 9. Thai Airways & \\
\hline & 5. Air New Zealand & 10. Malaysia Airlines & \\
\hline \multirow{5}{*}{2011} & 1. Qatar Airways & 6. Etihad Airways & \\
\hline & 2. Singapore Airlines & 7. Air New Zealand & \\
\hline & 3. Asiana Airlines & 8. Qantas Airways & \\
\hline & 4. Cathay Pacific Airways & 9. Turkish Airlines & \\
\hline & 5. Thai Airways International & 10. Emirates & \\
\hline \multirow{5}{*}{2012} & 1. Emirates & 6. Cathay Pacific Airways & \\
\hline & 2. Qatar Airways & 7. Etihad Airways & \\
\hline & 3. Singapore Airlines & 8. Garuda Indonesia & \\
\hline & 4. ANA All Nippon Airways & 9. Turkish Airlines & \\
\hline & 5. Asiana Airlines & 10. Qantas Airways & \\
\hline \multirow{5}{*}{2013} & 1. Emirates & 6. Cathay Pacific Airways & \\
\hline & 2. Qatar Airways & 7. Etihad Airways & \\
\hline & 3. Singapore Airlines & 8. Garuda Indonesia & \\
\hline & 4. ANA All Nippon Airways & 9. Turkish Airlines & \\
\hline & 5. Asiana Airlines & 10. Qantas Airways & \\
\hline
\end{tabular}

examinations on glocalism and uniforms are conducted. Second, airline uniforms are studied to see how the glocalism trend is reflected in terms of main design elements. Third, based on these, the aesthetic qualities are innate in airline uniforms where applying glocalism is induced.

The methodologies of research include advanced study concerning glocalism, uniform and regional garment traditions of the world, theoretical studies through academic journals, internet research and professional books, and case studies based on the female uniform imaged on each airline's website or internet. The scope of research is limited to female uniforms of flight attendants from 10 airlines reflecting glocalism as listed more than twice in the top ten 'The world's best airline' in the past five years from 2009 to 2013 whose selection process is based on the survey conducted by Skytrax which is the world's largest airline evaluation organization(Table 1).

\section{Theoretical Background}

\subsection{Definition of glocalism}

Glocalism is a cultural theory promoting the global level development of local areas which is a compound word meaning the coexisting phenomenon of globalization and localization, and an attitude of recognizing this phenomenon as a course of improvement(Hong, 2010).

Considering diverse preceding research related to glocalism, Lim and $\operatorname{Kim}(2013)$ mentioned that truthful globalization is considerate to all localities, referring to the necessity of cultural differences and integrations of markets and involving the actual meaning of "Think globally, Act locally." Kim(2013) suggested that glocalism is a word derived from a marketing business, asserting local products consumed at a global level and likewise, global level changes into the local level, and according to Yoon(2014), it is the macro localization of expanding the cultural values of the region to the world occurring together with the micro globalization of the localizing universal culture.

In other words, glocalism is the process of recognizing economy, culture and information multi-dimensionally, considering the global and local aspects simultaneously beyond the unilateral concept of globalization or localization and the idea creating another meaning as regions and the world are influenced by each other in the process.

This notion of glocalism is applied in a range of fields and it is visible in the course of establishing the integrated image of an air- 
line corporation, concretely materialized in uniforms that flight attendants are wearing at the very contact point of customer services. As a marketing tool of a corporation influencing the customers in accepting the recognition of the airline and as a result of a combination of local aesthetics where the airline is located with global aesthetics by glocalism, the uniform of a flight attendant contributes to the improvement of corporate performance.

\subsection{General analysis on airline uniforms}

According to 'The oxford advanced learner's dictionary', the uniform connotes "the special set of clothes worn by all members of an organization or a group at work, or by children at school" or "the clothes worn by the members of a sports team when they are playing". Originated from the military uniform, the uniform is a means of visually announcing the message of associated organization and it must satisfy the fundamental conditions of fashion design and be appropriate for the organization(Han, 1999). Han and Park(2005) mentioned that a uniform is an outer expression of socio-cultural inner implications, condensed into the symbolic concept of emphasizing social meaning and worn coherently to achieve a certain goal.

As such, this shows that a uniform is a non-verbal communication tool delivering organizational or private information by recognizing the uniform worn that displays internal meaning in consideration of the practical and functional aspects which must be accompanied for wearers and specific purposes and are the characters of the organization.

Among different uniforms worn in various fields, an airline uniform directly influences on airline image evaluation saddling the learning effect for passengers who have experienced the service attitudes of cabin crews wearing a uniform as a face representing the corporate or moving C.I(Corporation Identity)(Namkoong, 2011). The first airline uniform was in nursing that a nurse hired to be present at the Boeing Air Transport(UA) worn in 1930 and from that moment on, a uniform demonstrates the changes in compliance with the conditions of the times, for instance, a design applied to a military uniform was popular during the World War and currently it develops in a practical form, capturing the history and culture of each nation and individualities of each airline(Lim, 2005).

The flight uniforms that cabin crews are wearing today are a moving visual identity influencing the image formation of a corporation and a crucial factor for customers attaining services from a flight attendant in determining the airline. Visually presenting the airline's ideology, pursuing the values and unique characteristics through the coherent shape, color, and composition, a uniform is directly related to the corporate competitiveness as distinguished from other corporations and contributes in enhancing services and work performances(Kim \& Na, 2012). Therefore, a uniform plays the role of establishing the distinctive image of an airline by providing a visual experience and as a result, it is identified that each airline delivers the positive values of a corporation through a uniform design corresponding to the periodic sensibility.

\section{Expression tendency of glocalism in flight attendants' uniform design}

When it comes to deciding flight as a means of transportation, the psychological factor of the airline's image plays a critical role and it comes from the nature of the flight industry that each airline competes with others with the same type of aircrafts and limited destinations(Kim, 2004). Thus, each airline uses a uniform as a visual element to convey the corporate image more effectively when providing cabin services and the glocalism trend apparent in uniforms can be identified for each design element. In this chapter, to grasp expression tendency of glocalism in flight attendants' uniform design, the design elements of shape, color, and fabric were categorized and analyzed targeting flight attendants' uniform that were listed more than twice in the top ten 'The world's best airline' and given the limitations of the source materials as two dimensional images, the fabric related chapter was focused on patterns which were visually recognizable.

\subsection{Shape}

The shape is an element demonstrating the obvious visual changes in accordance with the flow of the time in terms of fashion design. Each airline displays their own image and identity through a design fulfilling the changes as time passes, maximizing that effect by reflecting glocalism.

The example of glocalism that has appeared in airline uniforms with respect to the design element of shape is the uniform of Cathay Pacific Airways which appropriates a certain aspect from the traditional Chinese dress Chi-pao(Fig. 1, 2). Originated from the Chinese Manchurian traditional garments, its typical features are a tight silhouette and standing collar set in the 1930s and by applying these formal qualities(Ryu et al., 2011), Cathay Pacific Airways presents the unique aesthetics of the traditional Chinese dress in contemporary shape. The uniforms of Emirate in Fig. 3 and Etihad Airways in Fig. 4 mirror the formal properties of the veil that females living in the United Arab Emirates wear conventionally(Fig. 5). There are different names and types of veils that females in the Islamic culture wear depending on regions, performing the practical function of blocking the sunlight and sandblast and an esthetic function of evoking a graceful ambience as long fabric swings(Hong et al., 2004; Seo, 2013). Adding the shape 


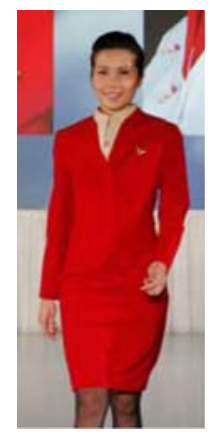

Fig. 1. A flight attendant's uniform of Cathay Pacific Airways http://www.cathaypacific.com

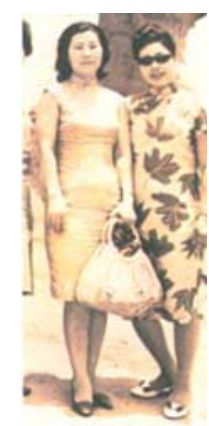

Fig. 2. Chinese dresses in 1960s. Traditional Costumes of Asia (2004), p. 43.

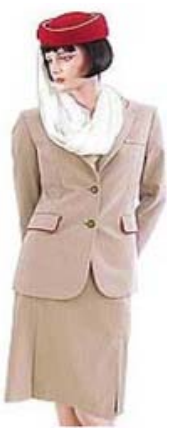

Fig. 3. A flight attendant's uniform of Emirates. http://www.uniformfreak.com
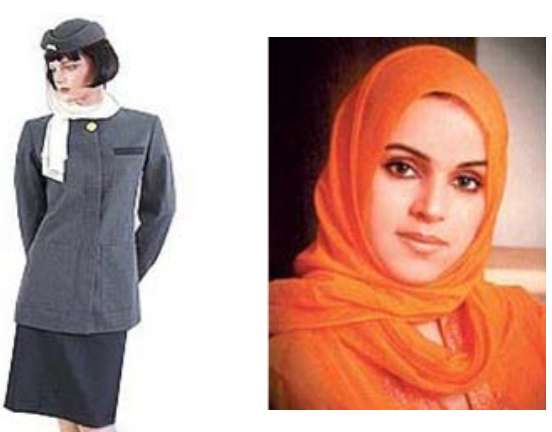

ig. 4. A flight attendant's Fig. 5. Hijab of a Musuniform of Etihad Air- lim woman. ways. http://www.uniformfreak.com of a veil on the general H-line suit skirt uniform design in keeping with the globalization trend, Emirates and Etihad Airways visualize the characteristics of Middle Eastern airlines, employing the traditional image as a distinctive element. The uniforms of the Garuda Indonesia and Malaysia Airlines from Southeast Asia employ the traditional local garment styles of the Kebaya and Sarong in their design(Fig. 6, 7, 8). It takes the features from the 'Kebaya' which is a caftan shape top and a cylindrical skirt of 'Sarong' modified in a contemporary style with a collarless jacket and long skirt, bringing out the formal beauty of the traditional garment naturally. Furthermore, the similar formal features of Southeast Asia's traditional garments were also applied to the uniform of Singapore Airlines which results from the historical background that the Malaysian airlines and Singapore Airlines have been operating separately from 1972 since the establishment of Malaysia Airlines in 1937("Rise of an Airline", 2014)(Fig. 9). The dissimilarity is that the uniform of Singapore Airlines transformed the straight neckline into a round one and shortened the top different from Malaysia Air- lines but the common feature of both airlines is a curved silhouette of a soft female body, creating comforting images for viewers. The Thai Airways uniform takes an ankle length skirt called Pah sin which is the shape of a traditional Thai garment 'Thai chakri' with Pha sabai, a cloth worn diagonally around the shoulder along with the traditional hair decoration of a Thai orchid as an ornamenting element of the shoulder area(Hong et al., 2004)(Fig. 10, 11).

As observed above, expression tendency of glocalism in flight attendants' uniform design in respect to the shape is presented in a way that reinvents and modernizes the shapes and ornamental elements of traditional garments worn in the nation or region in which airlines are located. This shows that each airline aims to establish brand identity through the visual differentiation of corporate images as the integrating characteristics of traditional garments into the uniform design.

\subsection{Color}

The color is a means to distinguish with other corporations and a

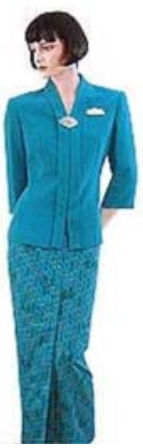

Fig. 6. A flight Garuda Indonesia. http:/ Malaysia Airlines. http:/ /www.uniformfreak.com /www.uniformfreak.com 73

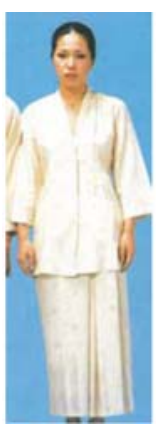

Fig. 8. Kebaya and Fig. 9. A flight sarong. A Folk Costume (1995), $p$. . 


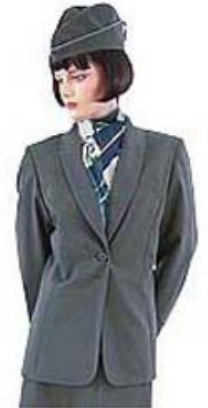

Fig. 12. A flight attendant's uniform of Air New Zealand. http://www.uniformfreak.com

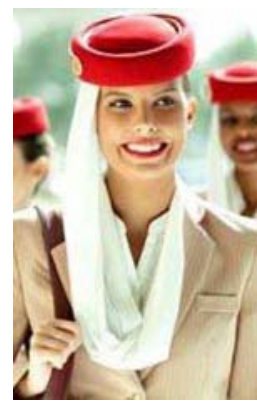

Fig. 13. A flight attendant's uniform of Emirates. http:// www.emiratesgroupcareers. com

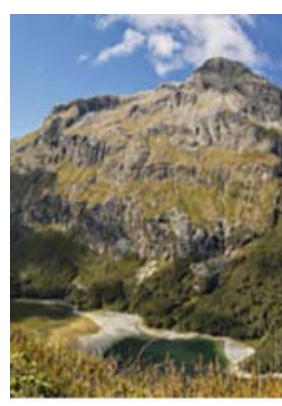

Fig. 14. Greenstone Valley in New Zealand. http://www.newzealand.com

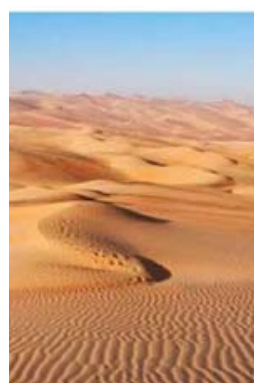

Fig. 15. Qasr al Sarab. http://www.visitabudhabi.ae

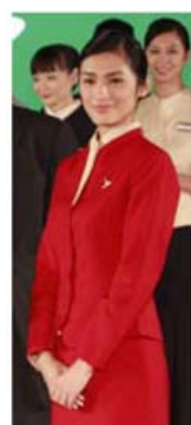

Fig. 16. A flight attendant's uniform of Cathay Pacific Airways.

http://www.cathaypacific.com visual language appealing to emotions where the color image sensed from a uniform is a strategic tool for establishing corporate identity and improving an airline's image(Kim \& Ra, 2012).

The cases presenting the glocalism trend in the color applications of airline uniforms are the Air New Zealand and Emirates which is a national airline of the United Arab Emirates(Fig. 12, 13), both employing natural colors from the regions that the airlines are affiliated. According to the announcement by the airline, the uniform of Air New Zealand is designed by Zambesi, reflecting the Greenstone color palette from the natural environment of New Zealand as pictured in Fig. 14("Air New Zealand unveils new Zambesi designed uniform", 2005) and for the case of Emirates, the uniform includes a red hat reminiscent of the sun, a cream color scarp representing the desert wind, and beige desert sand color for the entire look(Jeong et al., 2012)(Fig. 15). Likewise, airline uniforms that reflect the natural colors of the regions imply the national identity with visual differentiation from other airlines, and also deliver a comforting image for customers using the airline in association with the natural environment of their homeland. The uniform of Cathay Pacific Airways in Fig. 16 adopts red, a typical color rep- resenting China, Kwon and Kim(2005) explains that the red in China symbolizes an auspicious meaning like life, pleasure, joy, etc., conveying the typicality of Chinese culture visualizing communism in modern history. In other words, the color red of Cathay Pacific Airways' uniforms works as a sign expressing the nation's cultural identity further than the meaning of the red as one of the three primary colors. The purple and gold colors in the uniforms of Thai Airways which is the national airline of Thai are from the airline's logo signifying the national flower orchid and the temple("The history of Thai Airways", 2014) and this suggests that the natural image and religious character of Thai are reflected(Fig. 17, 18). In the world's largest orchid export county Thai, the purple orchid is one of the symbols of Thai in relation to the 'Royal Orchid' Service provided by Thai Airways(Fig. 20). And the temple is a center place for the people who value the Buddhist idea in the traditional Buddhist country Thai(The Korean Association of Thai Studies, 2000). That is, Thai Airways expressed the image of its homeland in the uniform by applying colors evoking the religious and natural environmental sense of the country.

As demonstrated in the above design analysis, the mode of

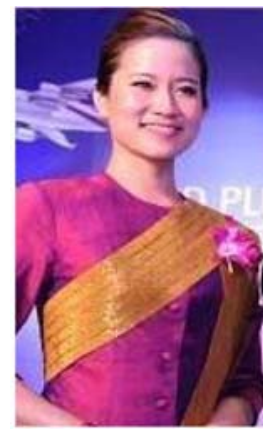

Fig. 17. A flight attendant's uniform of Thai Airways. http://www.prthaiairways.com
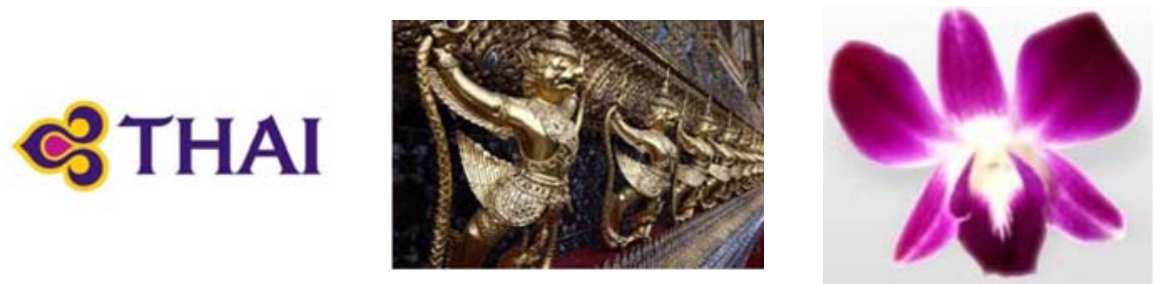

Fig. 19. 'Wat Phra Kaew' Temple (Bangkok in Thailand). http://www.visitthailand.or.kr
Fig. 20. Thailand's orchid. http://www.eurngluang.com http://www.thaiair.co. $k r$ 

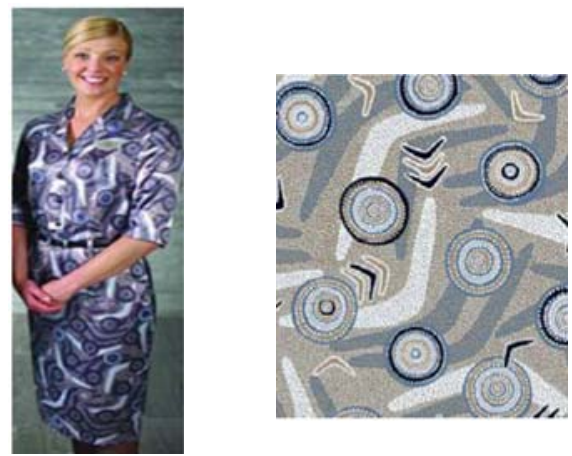

Fig. 21. A flight attendant's Fig. 22. A pattern of the uniform of Qantas Airways. Qantas Airways' uniform. http://www.ausbt.com.au http://www.jumbana.com.au

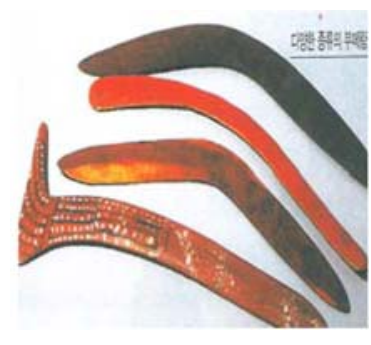

Fig. 23. Boomerang, Australia (2000), p. 191.

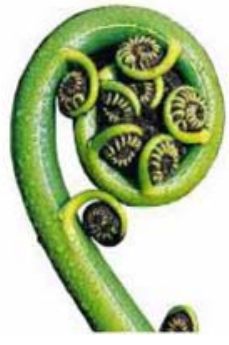

Fig. 24. Koru. http:// Fig. 25. A pattern of the Air

www.communityresear New Zealand's scarf. ch.org.nz

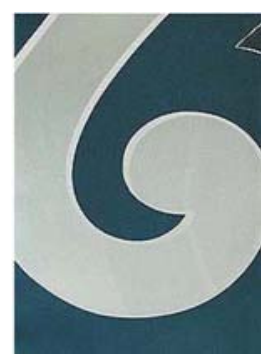

http://www.uniformfreak.com expressing the glocalism in airline uniforms in terms of color takes the form of using colors derived from natural, social, or cultural elements. Having national colors or hues symbolizing the architecture or natural environments of the nation, means the airline uniforms contribute to underlining the visually transference of familiar and relaxed images.

\subsection{Fabric}

Embedded with the aest hetic philosophies of a certain era or region, the design of the fabric is more than a pattern on a fabric drawn for the purpose of design development but a medium expressing the artistic sensibility. Accepting the cultural diversities of natural environments or historical backgrounds combined with universal modern aesthetics, a fabric design satisfies the tastes of modern people suggesting a new style(Park, 2006). The design development using patterns is demonstrated in airline uniforms which is a critical element visually carrying the characteristics of the airlines.

Examining the glocalism trend that has emerged in the fabric patterns of airline uniforms(Fig. 21), Qantas Airways based in Australia incorporated patterns conceived from the cultural heritage of the local Aborigine. The motif for the patterns used in the Qantas Airways' uniform is from the boomerang used by the Aborigine(Fig. 22, 23). They are considered to be the oldest surviving native of Australia(Han, 2006). As stated by Hong(2011), the boomerang for the Aborigine is not only a hunting tool but also an indispensable device for life as a war weapon, agricultural equipment, or musical instruments used in various rites, representing folk culture. Furthermore, the expression method using dot which is one of the techniques found in rock art was reflected in fabric design with the boomerang to show the 'Dream time' developed from the indigenous religion of Aborigines(Lee, 2000). In this way, Qantas Airways created the uniform accompanying local history as applying the Australian cultural product of the boomerang and the unique drawing technique for the uniform fabric pattern. Meanwhile, Air New Zealand employed the pattern for the scarp imagined from koru that most New Zealanders favor(Fig. 24, 25). It is a spiral shape of the fern starting to vegetate in the early spring in New Zealand and the word koru means a new life or beginning, mobility and growth in Maori language(Lee, 2008). Commonly seen in the craftworks of Maori or tattoos, the koru is a plant pattern used by the Maori as a creative and artistic design element(Lee, 2007) and that koru patterns on airline uniforms allow customers to share the sense of Maori culture indirectly. The patterns in Singapore Airlines and Malaysia Airlines were designed by the Batik method which is one of the representative dyeing techniques of Southeast Asian regions(Fig. 26, 27, 28). Originated from Indonesia in the mid- $19^{\text {th }}$ century, the Batik tradition was combined with modern attire as adopted for the nation's official garments afterward, said Cheong(2007). The two airlines took different approaches in designing the patterns and arranging colors appropriate for each corporation, creating unique uniforms reflecting the cultural heritage of Southeast Asian regions respectively. And designed by Jin Tae-Ok in 2003, the uniform of Asiana Airlines creates a sophisticated and elegant image of Korea effectively by partially using the traditional Korean Saekdong pattern(Jeong et al., 2012) (Fig. 29, 30). The Saekdong is a typical pattern representing the color arrangements of Korea as patch work and colorful silk stripes(Suh, 2009), applied in various design fields as a means to express korean aesthetic consciousness.

The glocalism trend in airline uniforms with regards to the fabric pattern is presented through external extractions by the dyeing technique or color arrangement or introduction of folk elements. It is evident that airlines are trying to establish distinctive visual images to unveil corporate and local identities by appropriating patterns of cultural or historical value for the uniforms of female flight attendants.

As was analyzed above, those diverse expression tendency of 


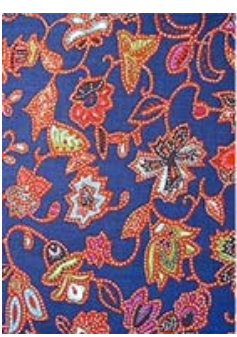

Fig. 26. A pattern of the uniform in Singapore Airlines. http:// www.uniformfreak.com

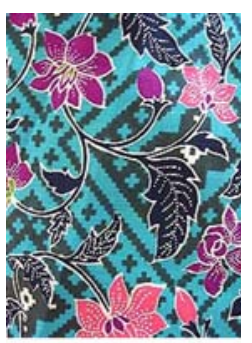

Fig. 27. A pattern of the uniform in Malaysia Airlines. http:// www.uniformfreak.com

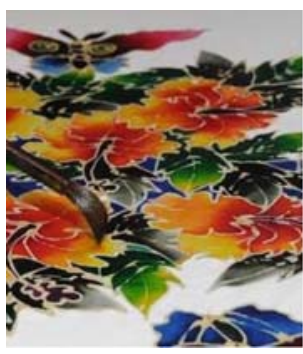

Fig. 28. Batik in Southeast Asia. http://www.globalwindow.org

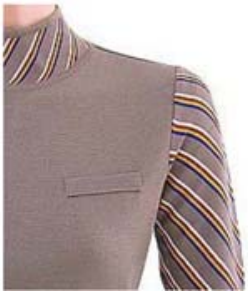

Fig. 29. A pattern of the uniform in Asiana Airlines. http://uniformfreak.com

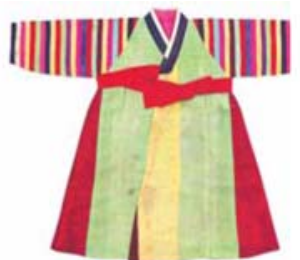

Fig. 30. Korean Saekdong. Korea's traditional colors (2012), p. 368

Table 2. Expression tendency of glocalism in flight attendants' uniform design

\begin{tabular}{cl}
\hline Design elements & \multicolumn{1}{c}{ Design analysis of the uniform } \\
\hline Shape & $\cdot$ Appropriate forms of traditional garments entirely or partially \\
& $\cdot$ application of ornamenting items(veil, Pha sabai) composing traditional garments \\
Color & $\cdot$ Derive colors from the natural environment of an airline's homeland \\
& $\cdot$ Apply symbolic color of the nation of an airline \\
& $\cdot$ Introduce environmental color from religious culture \\
Fabric & $\cdot$ Devise patterns based on natural motifs growing in the regions \\
& $\cdot$ Design fabrics reflecting folk tools(Boomerang) and drawing technique \\
\hline
\end{tabular}

glocalism in flight attendants' uniform design are on the basis of localities or cultural components, allowing an open-minded view and new directions for airline uniform design which visualizes corporate images. expression tendency of glocalism in flight attendants' uniform design are concluded as follows(Table 2).

\section{Aesthetic characteristics of glocalism in flight attendants' uniform design}

Today uniforms are worn for various fields such as sports and international events, medical organizations, public corporations, etc. and especially the marketing activities are implemented around flight attendants for airlines which are one of the major service oriented corporations(Kim, 2002). The cabin crews contribute directly to increasing customers as a mediator delivering an airline's message providing services for a long time in close contact with customers. Therefore, a uniform is a successful marketing tool for establishing a special and positive image which is different from other corporations.

Through analyzing on expression tendency of glocalism reflected in flight attendants' uniform design, the aesthetic characteristics in flight attendants' uniform design can be said to, first, the characteristic of traditionality was indicated. Sung and Lee(2004) mentioned that traditionality means a newly developed historical tendency expressing past design elements through comb- ing, reusing, or alluding to the process of not a simple historical reproduction but a transmission of a new image with both traditionality and modernity at the same time by the formality of times and creative will. That is, traditionality is a recreation of various expressive methods of the past for a novel design development in the modern fashion design field based on respect to cultural diversity. Traditionality is demonstrated in airline uniforms reflecting glocalism as in Fig. 1, 3, 4 and Fig. 6, 7, 9, 10 appropriating some parts from traditional garments or Fig. 16, using the symbolic colors of a specific nation. In terms of a pattern, traditionality is materialized through the embodiment of folk tools and the employment of drawing techniques as in Fig. 22 or the external reflection of traditional dyeing technique or color arrangement shown in Fig. 26, 27,29 . Through these ways, the airline uniform designs using the elements from traditional garments, folk traditions, or national colors convey a distinguishing corporate image inducing the positive images of the airline by adding the historical value of the nation on which the airline is based.

Secondly, a characteristic of natuality was shown. In accounting for naturality in modern society, Paik(2003) mentioned that it is an expression of modern people wishing to go back to the nature realized specifically and reflected in uniforms as adopting natural or similar colors and taking formal motifs providing psychological rest from the original nature. According to Song and Yang(1992), this culture of dressing can be identified as the tendency of taking 
Table 3. Aesthetic characteristics of glocalism in flight attendants' uniform design

\begin{tabular}{ll}
\hline Aesthetic characteristics of glocalism in flight attendants' uniform design \\
\hline Traditionality & $\begin{array}{l}\text { Create a new image by reinterpreting expression methods of design elements in the past from technique of expression in the present } \\
\text { Project the desire of modern people searching for mental rest as assimilated into pure nature like a natural object itself or a folklore } \\
\text { custom which is not processed at all }\end{array}$ \\
Compromisability & Restructure regional and traditional senses into universal and modern ones based on the magnanimity of embracing attitude
\end{tabular}

traditional customs and lifestyles as a means of expression, pursuing a life that goes with nature. Namely, naturality is a quality projecting the desire of modern people seeking comforts from something pure with no artificial or fictional procedures, expressed in the form of fashion using familiar colors or reflecting nature. The ways in which naturality is presented in the airline uniforms of glocalism qualities are visualized like in Fig. 16 and Fig. 20, using local color palettes where the airline is located, Fig. 17 with regional tones, or Fig. 25, developing patterns motivated from nature. Involving a regional environment and making use of natural objects, airline uniform designs likewise create a positive influence on corporation management by promoting a peaceful image to the modern people who try to find beauty in nature.

Thirdly, it showed the characteristic of compromisability. According to Park(2006), compromisability is what agrees with diversity as the 'possibility' to create something new by making incompatible elements coexist or combining completely repelling elements. And Shin(2001) argued that it is a witty mixture of style that has occurred in juxtaposition, recognizing the boundaries of styles from various cultures. Compromisability is, hence, a harmonious combination of modern and traditional or universal or local senses, speculating a variety of elements like shape, color, or fabric. Compromisability in the glocalism aspects of airline uniforms is clear in the formal integration of traditional and modern dressings. Take the examples of Fig. 1, 2 with Chi-pao features, Fig. 3, 4, 5 with the characteristics of Islamic veil tradition, Fig. 6, 7, 8, 9 with the coordination of Southeast Asian garments, and Fig. 10, 11 with Thai traditions. With respect to the fabric, the compromisability tendency is materialized by moderately describing the regional natural object like Fig. 25 or adopting the external properties of the traditional methods like Fig. 26, 27. To sum up briefly, compromisability in flight attendants' uniform design contributes to the establishment of the individualized images of the airlines corresponding to the post-modernistic ideas of modern people accepting cultural diversities by way of combining western female dressings and regional indigenous costume cultures. Aesthetic characteristics of glocalism in flight attendants' uniform design are as follows(Table 3).

\section{Conclusion}

The importance of non-verbal communication with the development of information delivery media is ever more increasing in the globalized modern society and corporations make diverse attempts to stimulate customers' senses for the establishment of superior and unique images of their own in competitions. Especially airline corporations where there is little difference in their work practices compared to other industries place emphasis on the development of uniforms to deliver their own image through a visual medium. And this research induced the aesthetic quality according to the glocalism tendencies through the analysis of airline cabin crew's uniforms and the conclusion is as below.

The glocalism trends discovered through the airline uniform design analyses are first, the unique silhouette of traditional garments are appropriated or the ornamental items conveying the religious or national properties are applied and secondly, the color palettes represent the images of nations or natural environments with which the airlines are affiliated. Thirdly, in terms of fabric design, the glocalism trend is displayed as taking motifs from the natural object of the region or traditional tools of historic values or adopting traditional drawing techniques.

Through expression tendency of glocalism, aesthetic characteristics of glocalism in flight attendants' uniform design, first, include traditionality. It is an expression through the modernistic interpretation of traditional aesthetic consciousness, entailing the historical value and identity of the airline's native land through the application of the shape and color of traditional costumes, folklore equipment, or patterns of traditional drawings. Then, it also shows aesthetic characteristic of naturality. It is a restructuring of untainted nature like natural objects or folklore customs expressed by using color palettes suggesting the natural environment of the location on which the corporate image is based or employing patterns taken from the plants as a symbolic image of nature. Finally, there is aesthetic characteristic of compromisability. Materialized by combining the diverse cultural aspects with the universal senses, the compromisability demonstrates modern yet traditional sensibility through the coordination of standardized uniform with the 
aesthetic beauty of traditional garments or local colors with the shape of traditional costume.

Applied in the development of a new uniform design, the glocalism trend as one of the diverse flows of modern fashion industries is utilized as a means to symbolize a corporation visually. These creative attempts of transforming each region's traditional garments and combining the natural and cultural environments contributed to the establishment of unique images for airlines giving original aesthetic qualities to the uniforms of female flight attendants and also it stimulates the sensitivities of customers flying with the airline. As evidenced likewise, the introduction of the glocalism in the fashion industry is likely to supplement a wide range of garment development as a design satisfying the aesthetic desires of the modern people who follow individuality. In addition, it should be disclosed that for this research on the airline uniforms, the analysis in terms of fabric was conducted focused only on patterns due to the limitations of visual resources so that further research is expected to be more detailed on the types and structure of fabrics used in airline uniforms and also the transformation aspects of the periodic aesthetic consciousness according to the analysis of the change of airline uniforms reflecting glocalism.

\section{References}

A flight attendant's uniform of Air New Zealand. Cliff Muskiet. (n. d.). Air New Zealand/NewZealand. Cliff Muskiet's stewardess/flight attendant uniform collection. Retrieved October 13, 2013, from http:/ /www.uniformfreak.com/1airnewzealand.html

A flight attendant's uniform of Cathay Pacific. 'Cathay Pacific launches new uniform for frontline staff worldwide'. (2011, June 22). Cathay Pacific Airways. Retrieved July 12, 2014, from http:/ /www.cathaypacific.com/cx/en_VN/about-us/press-room/pressrelease/2011/cathay-pacific-launches-new -uniform-for-frontlinestaff-worldwide.html

A flight attendant's uniform of Emirates. Cliff Muskiet. (n. d.). Emirates/United Arab Emirates. Cliff Muskiet's stewardess/flight attendant uniform collection. Retrieved October 13, 2013, from http://www.uniformfreak.com/1emirates.html

A flight attendant's uniform of Emirates. 'Cabin Crew'. (n. d.). The Emirates Group. Retrieved July 22, 2014, from http://www. emiratesgroupcareers.com/english/Careers_Overview/cabin crew/ default.aspx

A flight attendant's uniform of Etihad Airways. Cliff Muskiet. (n. d.). Ethihad Airways/The United Arab Emirates. Cliff Muskiet's stewardess/flight attendant uniform collection. Retrieved October 13, 2013, from http://www.uniformfreak.com/letihad.html

A flight attendant's uniform of Garuda Indonesia. Cliff Muskiet. (n. d.). Garuda Indonesia/Indonesia. Cliff Muskiet's stewardess/flight attendant uniform collection. Retrieved October 13, 2013, from http://www.uniformfreak.com/1garuda.html

A flight attendant's uniform of Malaysia Airlines. Cliff Muskiet. (n. d.). Malaysia Airlines/Malaysia. Cliff Muskiet's stewardess/flight attendant uniform collection. Retrieved October 13, 2013, from http://www.uniformfreak.com/1malaysia.html

A flight attendant's uniform of Qantas Airways. 'Our Portfolio'. (n. d.). The Jumbana group. Retrieved July 12, 2014, from http:// jumbana.com.au/our-portfolio/

A flight attendant's uniform of Singapore Airlines. Cliff Muskiet. (n. d.). Singapore Airlines/Singapore. Cliff Muskiet's stewardess/flight attendant uniform collection. Retrieved October 13, 2013, from http://www.uniformfreak.com/1singaporeairlines.html

A flight attendant's uniform of Thai Airways. 'THAI Takes Delivery of its First A380'. (2012, September 28). Thai Airways. Retrieved July 27, 2014, from http://www.prthaiairways.com/news/node/ 409.html

A Kebaya and a sarong, Fashion Design Association. (1995). A folk costume. Seoul: Hakmoon-sa.

'Air New Zealand unveils new Zambesi designed uniform'. (2005, October 16). Air New Zealand. Retrieved June 15, 2014, from http://www.airnewzealand.co.nz/press-release-2005-airnz-unveilsnew-uniform-16oct05

A pattern of the Air New Zealand's scarf. Cliff Muskiet. (n. d.). Air New Zealand /New Zealand. Cliff Muskiet's stewardess/flight attendant uniform collection. Retrieved October 13, 2013, from http://www.uniformfreak.com/1airnewzealand.html

A pattern of the Qantas Airways' uniform. 'Our Portfolio'. (n. d.). Jumbana group. Retrieved July 12, 2014, from http://jumbana. com.au/our-portfolio/

A pattern of the uniform in Asiana Airlines. Cliff Muskiet. (n. d.). Asiana Airlines/South Korea. Cliff Muskiet's stewardess/flight attendant uniform collection. Retrieved October 13, 2013, from http://www.uniformfreak.com/1asiana.html

A pattern of the uniform in Malaysia Airlines. Cliff Muskiet. (n. d.). Malaysia Airlines/Malaysia. Cliff Muskiet's stewardess/flight attendant uniform collection. Retrieved October 13, 2013, from http://www.uniformfreak.com/1malaysia.html

A pattern of the uniform in Singapore Airlines. Cliff Muskiet. (n. d.). Singapore Airlines/Singapore. Cliff Muskiet's stewardess/flight attendant uniform collection. Retrieved October 13, 2013, from http://www.uniformfreak.com/1singaporeairlines.html

Im, J. S., \& Kim, Y. S. (2013). A study on glocal contents planning and strategy of address in local television : Focused on outcomes and limits of 'Great flight' in KNN. Journal of Media Economics \& Culture, 11(1), 47-87.

Cheong, S. K. (2007). Study on the Batik in contemporary fashion design : Focusing on Malaysia and international fashion collections. Unpublished master's thesis, Hongik University, Seoul.

Choi, K. S. (2009). The history of glocalization. The Journal of the Humanities, 57, 1-32.

Clothes Design Association. (1995). A folk costume. Seoul: Kyomoonsa. Greenstone Valley in New Zealand, Julian Apse. (n. d.). 'Tourism New Zealand'. Grand traverse guided walk - Ultimate Hikes. Retrieved July 29, 2014, from http://www.newzealand.com/int/plan/business/ grand-traverse-guided-walk-ultimate-hikes/

Han, M. S. (1999). An analysis of the symbol system of airline flight attendant uniform. The Research Journal of the Costume Culture, $7(6), 857-870$

Han, S. J. (2006). A case study on the development of cultural artifacts by utilizing Australian aborigine art. Journal of Korea Design 
Forum, 14, 465-477.

Han, Y. H., \& Park, M. H. (2005). The plasticity of uniform design (Part I). Journal of the Korean Society of Clothing and Textiles, 29(5), 649-661.

Hijab of a Muslim woman. 'Hijab'. (2007, May 09). irfi.org. Retrieved Aug 10, 2014, from http://www.irfi.org/articles/articles_1101_1150/ hijab.htm

Hong, N. Y., Shin, H. S., \& Choi, J. H. (2004). Traditional costumes of Asia, (1st ed.). Seoul: Kyomoonsa.

Hong, S. K. (2010). Glocalism and local culture as a suggestion for a joint research. Journal of Sokdang Academic Research of Traditional Culture, 46, 1-17.

Hong, S. R. (2011). The study of the culture and art of aborigines with geographical relic and mythology. Journal of the Association of Korean Photo-Geographers, 21(4), 117-125.

Jeong, J. C., Park, S. K., \& Min, S. J. (2012). A study on uniform design of female flight attendants using Korean images. Journal of the Korean Society of Fashion Design, 12(1), 55-73.

Jeong, Y. S. (2012, May 11). The artisan spirit of Malaysia in Batik. KOTRA \& globalwindow.org. Retrieved October 13, 2013, from http://www.globalwindow.org/GW/global/trade/economy-trend/ overseamarket-detail.html

Kim, E. S. (2002). A study in the effect of image of cabin crews upon airlines image. Unpublished master's thesis, Jeonju University, Jeonju.

Kim, J. U., \& Kim, Y. S. (2013, November 16). Aesthetic characteristics of flight attendants' uniform reflecting Glocalism. Proceedings of the Society Fashion \& Textile Industry, Fall Conference, Korea, p. 125.

Kim, K. H., \& Ra, J. Y. (2012). A study of influences color image upon brand personality and brand identity -The case of Korean Air-. Journal of Korea Society of Design Forum, 36, 303-313.

Kim, K. Y., \& Na, H. S. (2012). Uniform design development for the low-cost airline flight attendant. Journal of Korea Design Forum, $36,149-160$.

Kim, M. S., \& Park, H. Y. (2013). The effects of flight attendant's uniform design on uniform satisfaction and select airline. Journal of the Korea Society of Computer and Information, 18(9), 189199. doi:10.9708/jksci.2013.18.9.189

Kim, S. Y. (2013). Glocalism trend in the pictorials of domestic licensed fashion magazines. Journal of the Korean Society of Fashion Design, 13(1), 47-69.

Koru. 'Fulbright Seminar: Veronica Tawhai - Transforming Citizenship Education 31 May'. (2013, May 9). Tangata Whenua, Community and Voluntary Sector Research Centre Community Research. Retrieved July 6, 2013, from http://www.communityresearch.org.nz/ news/fulbright-seminar-veronica-tawhai-transforming-citizenshipeducation-31-may

Kwon, G. Y. (2011). The study of symbolic images in modern fashion design adopting the dualistic meanings of uniform. Fashion \& Textile Research Journal, 13(4), 478-486.

Kwon, Y. G., \& Kim, N. R. (2005). A study on the signification and symbol of RED in Korea, China and Japan. Journal of Korean Society of Color Studies, 19(2), 21-36.

Lee, D. A. (2000). Australia (1st ed.). Seoul: Pooreungil.

Lee, N. I. (2008). New Zealand (1st ed.). Seoul: Jeulgeoun-sangsang.

Lim, H. M. (2005). A research on the uniform replacement for airlines` image marketing strategy -Focused on flight attendant uniform-.
Journal of Communication Design, 19, 29-38.

Lim, J. S., \& Kim, Y. S. (2013). A study on glocal contents planning and strategy of address in local television : Focused on outcomes and limits of 'Great flight' in KNN. Journal of Media Economics \& Culture, 11(1), 47-87.

Mun, E. B. (2012). Korea's traditional colors (1st ed.). Gyeonggi: Ahn graphics.

Namkoong, J. L. (2011). Effects of cognitive and emotional image according to low-cost carriers flight attendant's uniforms on customer loyalty. Unpublished master's thesis, Sejong University, Seoul.

Paik, I. H. (2003). A study on the "Organic" phenomenon in modern fashion. Unpublished master's thesis, Kookmin University, Seoul.

Park, N. S. (2006). Eclectic trends and characteristics in modern textile design. Journal of Korean Society of Design Science, 19(1), 303-316.

Qasr al Sarab, 'QASR AL SARAB'. (n. d.). Visit Abu Dhabi. Retrieved July 29, 2014, from http://visitabudhabi.ae/en/what.to.do/explore.our. desert/qasral.sarab.aspx

'Rise of an Airlines'. (2014). Malaysia Airlines. Retrieved June 2, 2014, from http://www.malaysiaairlines.com/content/mas/my/en/ corporate-info/our_story/about-us.html

Ryu, S., Jang, J. I., \& Lee, Y. H. (2011). The characteristics of the Qipao design in contemporary fashion design -Focused on women's collections from 2000 to 2009-. The Research Journal of the Costume Culture, 19(2), 296-308.

Seo, M. H. (2013). A study on the Ambivalence of the Muslim Women's Veil. Unpublished master's thesis, Pusan National University, Busan.

Shin, J. R. (2001). A study on the fusion image of modern fashion. Unpublished master's thesis, Sejong University, Seoul.

'Singapore girl'. (n. d.). Singapore Airlines. Retrieved August 15, 2013, from http://www.singaporeair.com/ko_KR/flying-with-us/ singaporegirl/

Song, M. J., \& Yang, S. H. (1992). The study of exoticism in western costume. Journal of the Korean Society of Costume, 18, 291-306.

Suh, O. K. (2009). A study on design of culture goods using cloth with sackdong. Journal of the Korean Society of Design Culture, 15(3), 153-160.

Sung, K. S., \& Lee, S. H. (2004). The aesthetics consciousness of voluminous enlargement in the western costume -In the 20th century-. Journal of Korean Society of Costume, 54(7), 151-164.

Thailand's orchid. 'About Eurng Lurang'. (n. d.). Thai Catering Department. Retrieved July 29, 2014, from http://www.eurngluang. com/eurngluang/en/about/

The history of Thai Airways. 'introduction and history'. (n. d.). Thaiair. Retrieved June, 15, 2014, from https://www.thaiair.co.kr/ 01 introduction/history.html

The Korean Association of Thai Studies. (2000). Thailand (2nd ed.). Seoul: Hankuk University of Foreign Studies Press Center.

'Uniform'. (n. d.). 'Oxford University Press'. Retrieved July 28, 2014, from http://www.oxfordlearnersdictionaries.com/definition/english/ uniform_1

The logo of Thai Airways. 'introduction and history'. (n. d.). Thai Airways. Retrieved June 29, 2014, from https://www.thaiair.co.kr/ 01 introduction/history.html

'Wat Phra Kaew' Temple (Bangkok in Thailand), 'Grand Palace \& Wat Phra Kaew’. (2013, November 23). TAT Seoul Office. 
Retrieved June 29, 2014, from http://www.visitthailand.or.kr/ home/info.php?mid=134\&treec=22\&ctg1=11\#.U9ci52AcSM8

Yoon, H. J. (2014). Study on the direction of the design strategy for the glocal brand of Kimchi. The Journal of Brand Design Association of Korea, 12(1), 169-180.

(Received 5 September 2014; 1st Revised 22 October 2014; 2nd Revised 25 November 2014; Accepted 30 December 2014)

(C) 2015 (by) the authors. This article is an open access article distributed under the terms and conditions of the Creative Commons Attribution license (http://creativecommons.org/licenses/by/3.0/), which permits unrestricted use, distribution, and reproduction in any medium, provided the original work is properly cited. 